\title{
Canalicular laceration visualisation using chandelier illumination
}

\author{
Amar Pujari, Pallavi Singh, Sahil Agrawal, Mandeep S Bajaj
}

Dr Rajendra Prasad Centre for Ophthalmic Sciences, All India Institute of Medical Sciences, New Delhi, Delhi, India

\section{Correspondence to} Dr Amar Pujari, dramarpujari@gmail.com

Accepted 22 January 2019

\section{DESCRIPTION}

A 45-year-old male patient rushed to ocular emergency for right upper and lower eyelid laceration following a road traffic accident. Examination revealed a visual acuity of 20/20 with normal anterior and posterior segments in both the eyes. Right upper and lower eyelids showed full thickness discontinuity just medial to the caruncle. After obtaining consent for surgical repair under local anaesthesia, the extent of canalicular injury was delineated but the torn medial and lateral ends were not completely made out. Thus, after punctal dilatation, a chandelier illumination probe was introduced through the lower punctum. As the probe was advanced, the lateral torn end of the lower canaliculus became more visible (figure 1A). Thereafter further advancement, the probe was negotiated through the torn end, and the bright illumination helped to confirm the actual location of the lateral torn margin of the canaliculus (figure 1B). In the same manner the upper punctum was visualised (figure 1C,D).

Now, to identify the medial end, the illuminated chandelier probe was passed through one of the visible medial ends of the torn canaliculus. The other end was visualised as a prominent dull red slit-shaped inferior opening in the background of uniformly red soft tissue
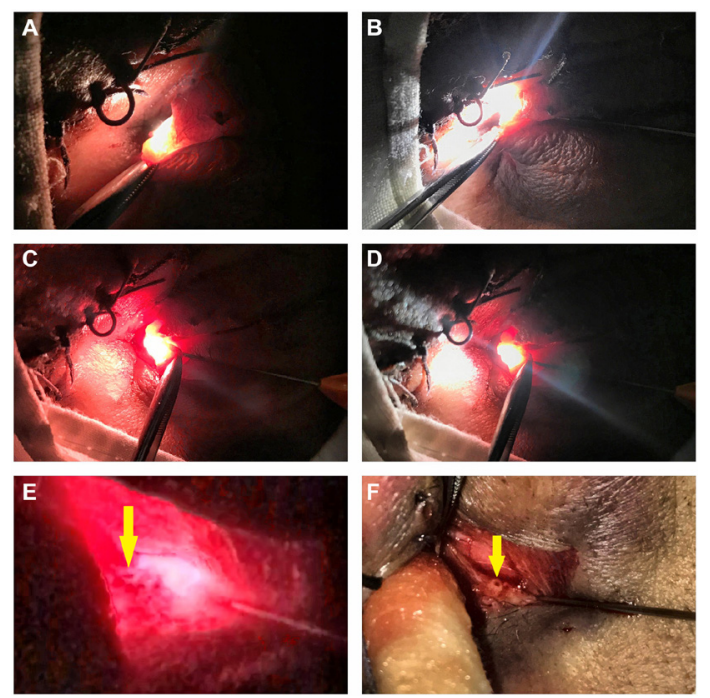

Figure 1 (A) Chandelier illumination-guided visualisation of the lateral torn end of the lower canaliculus. (B) The illumination probe guided through the lower canaliculus. (C) Lateral torn end of the upper canaliculus visualisation through the illumination probe. (D) After passing the probe through the torn lateral end. (E) Through the medial upper torn canaliculus, the illumination was placed, and the lower end was confirmed. (F) Clinical visualisation of the lower medial canaliculus. (figure 1E). The same was confirmed following the removal of the illumination probe (figure $1 F$ ). The stent was placed, and the lacerations were closed.

In ocular emergencies, eyelid injuries are routinely encountered. Each case poses a different challenge for the surgeon. Therefore, it is very important to tackle these cases with extra care and innovation every time.

While repairing complex canalicular lacerations, careful observation of the torn end to achieve perfect apposition is very crucial to achieve symptom-free postoperative outcomes. Injecting air, fluorescein dye or viscoelastic substances from one punctum to identify the other end has been described traditionally. ${ }^{1}$ However, this may not be effective under all circumstances.

Peng et al described a method to identify torn ends of the canaliculus using a 23 Ga fibre optic probe. However, the technique was demonstrated via diagrams instead of clinical photographs of practical cases. ${ }^{2}$ The basic concept in both the methods remains the same, that is, exploration of the torn end of the canaliculus with the help of an illuminating source, but the intraoperative challenges need a detailed discussion with the help of a practical case. Therefore, here in this report, using a chandelier illumination, we have demonstrated the identification of medial and lateral torn ends of the canaliculus in a systematic way. This report proposes to further explore the role of these techniques in canalicular injuries.

\section{Learning points}

- Complex canalicular laceration repair is always a challenge.

- In addition to routine modalities, chandelier illumination can be used for the identification of torn lateral and medial ends in cases of bicanalicular laceration.

Contributors AP, PS, SA and MSB have evaluated the case in detail followed by optimal intervention to a good outcome. AP, PS SA and MSB after critically analysing the case wrote the report together.

Funding The authors have not declared a specific grant for this research from any funding agency in the public, commercial or not-for-profit sectors.

Competing interests None declared.

Patient consent for publication Not required.

Provenance and peer review Not commissioned; externally peer reviewed.

\section{REFERENCES}

1 Örge FH, Dar SA. Canalicular laceration repair using a viscoelastic injection to locate and dilate the proximal torn edge. J Aapos 2015;19:217-9.

2 Peng W, Wang Y, Tan B, et al. A new method for identifying the cut ends in canalicular laceration. Sci Rep 2017;7:43325. 
Copyright 2019 BMJ Publishing Group. All rights reserved. For permission to reuse any of this content visit https://www.bmj.com/company/products-services/rights-and-licensing/permissions/

BMJ Case Report Fellows may re-use this article for personal use and teaching without any further permission.

Become a Fellow of BMJ Case Reports today and you can:

- Submit as many cases as you like

- Enjoy fast sympathetic peer review and rapid publication of accepted articles

Access all the published articles

- Re-use any of the published material for personal use and teaching without further permission

For information on Institutional Fellowships contact consortiasales@bmjgroup.com

Visit casereports.bmj.com for more articles like this and to become a Fellow 